\title{
Compilation of Water-Resources Data for Montana, Water Year 2006
}

Compiled By P.B. Ladd, W.R. Berkas, M.K. White, K.A. Dodge, and F.A. Bailey

Prepared in cooperation with the State of Montana and other agencies

Open-File Report 2007-1346 


\section{U.S. Department of the Interior DIRK KEMPTHORNE, Secretary}

\section{U.S. Geological Survey \\ Mark D. Myers, Director}

\section{U.S. Geological Survey, Reston, Virginia: 2007}

For product and ordering information:

World Wide Web: http://www.usgs.gov/pubprod

Telephone: 1-888-ASK-USGS

For more information on the USGS — the Federal source for science about the Earth, its natural and living resources, natural hazards, and the environment:

World Wide Web: http://www.usgs.gov

Telephone: 1-888-ASK-USGS

Any use of trade, product, or firm names is for descriptive purposes only and does not imply endorsement by the U.S. Government.

Although this report is in the public domain, permission must be secured from the individual copyright owners to reproduce any copyrighted materials contained within this report.

Suggested citation:

Ladd, P.B., Berkas, W.R., White, M.K., Dodge, K.A., Bailey, F.A., 2007, Compilation of water-resources data for Montana, water year 2006: U.S. Geological Survey Open-File Report 2007-1346, 17 p. 


\section{Contents}

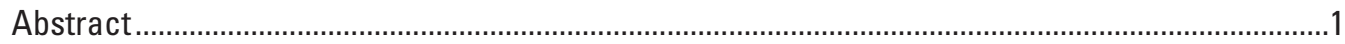

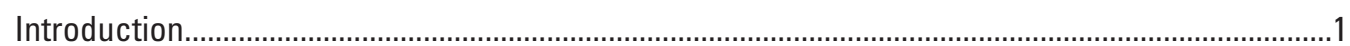

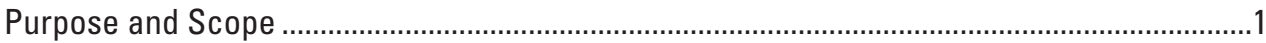

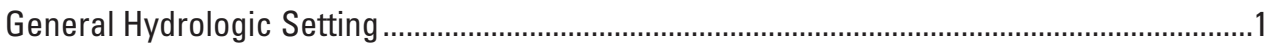

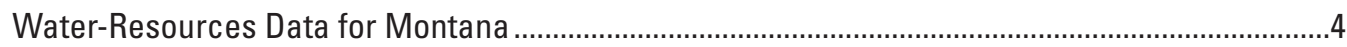

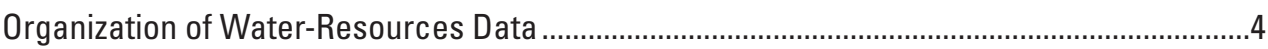

Documentation, Definition of Terms, and Related Water-Resources Information ....................4

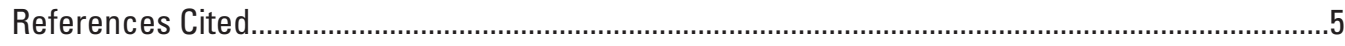

Appendix 1. Hudson Bay Basin: Stations-05013900 Grinnell Creek at Grinnell Glacier near Many Glacier, to 05020500 St. Mary River at international boundary and Upper Missouri River Basins: 06006000 Red Rock Creek above Lakes, near Lakeview, to 06090300 Missouri River near Great Falls

Appendix 2. Lower Missouri River Basin: Stations-06090650 Lake Creek near Power, to 06185500 Missouri River near Culbertson.......................................................................

Appendix 3. Yellowstone River Basin: Stations-06186500 Yellowstone River at Yellowstone Lake outlet, Yellowstone National Park, to 06329500 Yellowstone River near Sidney

Appendix 4. Columbia River Basin (Pend Oreille Basin): Stations-12301300 Tobacco River near Eureka, to 12391400 Clark Fork below Noxon Rapids Dam, near Noxon ...........13

Appendix 5. Montana's Ground-Water Monitoring Network ....................................................15

Appendix 6. National Atmospheric Deposition Program Precipitation Stations ..........................16

Appendix 7. Alphabetical Listing of Site-Data Sheets for Montana ...........................................17

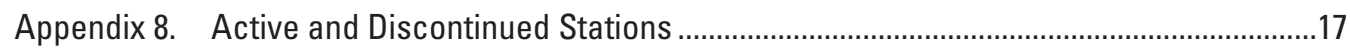

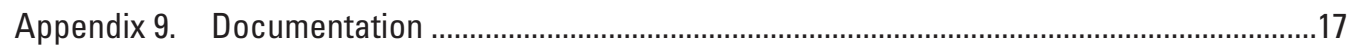

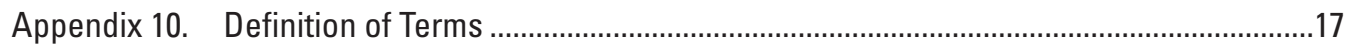

\section{Figure}

1. Map showing general geographic features of Montana ..................................................... 


\section{Conversion Factors, Datums, Abbreviated Water-Quality and Discharge Units, Symbols, Acronyms, and Water-Year Definition}

\begin{tabular}{|c|c|c|}
\hline Multiply & By & To obtain \\
\hline \multicolumn{3}{|c|}{ Length } \\
\hline inch (in.) & 2.54 & centimeter $(\mathrm{cm})$ \\
\hline inch (in.) & 25.4 & millimeter (mm) \\
\hline foot $(\mathrm{ft})$ & 0.3048 & meter $(\mathrm{m})$ \\
\hline mile (mi) & 1.609 & kilometer (km) \\
\hline \multicolumn{3}{|c|}{ Area } \\
\hline acre & 4,047 & square meter $\left(\mathrm{m}^{2}\right)$ \\
\hline acre & 0.4047 & square hectometer $\left(\mathrm{hm}^{2}\right)$ \\
\hline acre & 0.004047 & square kilometer $\left(\mathrm{km}^{2}\right)$ \\
\hline square mile $\left(\mathrm{mi}^{2}\right)$ & 2.590 & square kilometer $\left(\mathrm{km}^{2}\right)$ \\
\hline \multicolumn{3}{|c|}{ Volume } \\
\hline cubic foot $\left(\mathrm{ft}^{3}\right)$ & 28.32 & cubic decimeter $\left(\mathrm{dm}^{3}\right)$ \\
\hline cubic foot $\left(\mathrm{ft}^{3}\right)$ & 0.02832 & cubic meter $\left(\mathrm{m}^{3}\right)$ \\
\hline acre-foot (acre-ft or ac-ft) & 1,233 & cubic meter $\left(\mathrm{m}^{3}\right)$ \\
\hline acre-foot (acre-ft or ac-ft) & 0.001233 & cubic hectometer $\left(\mathrm{hm}^{3}\right)$ \\
\hline \multicolumn{3}{|c|}{ Flow rate } \\
\hline $\begin{array}{l}\text { cubic foot per second }\left(\mathrm{ft}^{3} / \mathrm{s} \text { or }\right. \\
\mathrm{cfs})\end{array}$ & 0.02832 & cubic meter per second $\left(\mathrm{m}^{3} / \mathrm{s}\right)$ \\
\hline $\begin{array}{l}\text { cubic foot per second per square } \\
\text { mile }\left[\left(\mathrm{ft}^{3} / \mathrm{s}\right) / \mathrm{mi}^{2} \text { or } \mathrm{cfsm}\right]\end{array}$ & 0.01093 & $\begin{array}{l}\text { cubic meter per second per } \\
\text { square kilometer }\left[\left(\mathrm{m}^{3} / \mathrm{s}\right) / \mathrm{km}^{2}\right]\end{array}$ \\
\hline gallon per minute (gal/min) & 0.06309 & liter per second $(\mathrm{L} / \mathrm{s})$ \\
\hline inch per year (in/yr) & 25.4 & millimeter per year (mm/yr) \\
\hline \multicolumn{3}{|c|}{ Mass } \\
\hline ton, short $(2,000 \mathrm{lb})$ & 0.9072 & megagram $(\mathrm{Mg})$ \\
\hline ton per day (ton/d) & 0.9072 & metric ton per day \\
\hline ton per day (ton/d) & 0.9072 & megagram per day (Mg/d) \\
\hline
\end{tabular}

Temperature in degrees Celsius $\left({ }^{\circ} \mathrm{C}\right)$ may be converted to degrees Fahrenheit $\left({ }^{\circ} \mathrm{F}\right)$ as follows:

$$
{ }^{\circ} \mathrm{F}=\left(1.8 \times{ }^{\circ} \mathrm{C}\right)+32
$$

Temperature in degrees Fahrenheit $\left({ }^{\circ} \mathrm{F}\right)$ may be converted to degrees Celsius $\left({ }^{\circ} \mathrm{C}\right)$ as follows:

$$
{ }^{\circ} \mathrm{C}=\left({ }^{\circ} \mathrm{F}-32\right) / 1.8
$$

Vertical coordinate information is referenced to National Geodetic Vertical Datum of 1929 (NGVD 29), North American Vertical Datum of 1988 (NAVD 88), or the Canadian Geodetic Vertical Datum of 1928.

Horizontal coordinate information is referenced to North American Datum of 1927 (NAD 27) or North American Datum of 1983 (NAD 83).

Altitude, as used in this report, refers to distance above the vertical datum. 


\title{
Abbreviated water-quality and discharge units used in this report:
}

\author{
cfs cubic feet per second \\ cfsm cubic feet per second per square mile \\ $\mu \mathrm{g} / \mathrm{g} \quad$ micrograms per gram \\ $\mu \mathrm{g} / \mathrm{L} \quad$ micrograms per liter \\ $\mu \mathrm{g} / \mathrm{mL} \quad$ micrograms per milliliter \\ $\mu \mathrm{S} / \mathrm{cm} \quad$ microsiemens per centimeter at 25 degrees Celsius \\ $\mathrm{mg} / \mathrm{L} \quad$ milligrams per liter \\ $\mathrm{mm} \quad$ millimeters \\ $\mathrm{mm} \mathrm{Hg} \quad$ millimeters of mercury \\ $\mathrm{ng} / \mathrm{L} \quad$ nanograms per liter
}

\section{Symbols used in this report:}

$\begin{array}{ll}\text { e } & \text { Estimated } \\ \text { E } & \text { Estimated } \\ < & \text { less than }\end{array}$

\section{Acronyms used in this report:}

FNU formazin nephelometric units

NTRU nephelometric turbidity ratio units

NWISWeb National Water Information System Web page

PDF portable document format

SDS site-data sheet

USGS U.S. Geological Survey

WDR Water-Data Report

WSP Water-Supply Paper

WY water year

\section{Water-year definition:}

Water year is the 12-month period from 0ctober 1 through September 30 of the following calendar year. The water year is designated by the calendar year in which it ends.

For example, water year 2006 is the period from October 1, 2005, to September 30, 2006. 


\title{
Compilation of Water-Resources Data for Montana, Water Year 2006
}

\author{
Compiled by P.B. Ladd, W.R. Berkas, M.K. White, K.A. Dodge, and F.A. Bailey
}

\section{Abstract}

The U.S. Geological Survey, Montana Water Science Center, in cooperation with other Federal, State, and local agencies, and Tribal governments, collects a large amount of data pertaining to the water resources of Montana each water year. This report is a compilation of Montana site-data sheets for the 2006 water year, which consists of records of stage and discharge of streams; water quality of streams and ground water; stage and contents of lakes and reservoirs; water levels in wells; and precipitation data. Site-data sheets for selected stations in Canada and Wyoming also are included in this report. The data for Montana, along with data from various parts of the Nation, are included in "Water-Resources Data for the United States, Water Year 2006," which is published as U.S. Geological Survey Water-Data Report WDR-US-2006 and is available at http://pubs.water.usgs.gov/wdr2006. Additional water year 2006 data collected at crest-stage gage and miscellaneous-measurement stations were collected but were not published. These data are stored in files of the U.S. Geological Survey Montana Water Science Center in Helena, Montana, and are available on request.

\section{Introduction}

Water is one of Montana's most valued renewable resources. A continuing supply of fresh water is vital to the future health and economic welfare of the people of Montana. Montana's water resources include surface water and ground water from diverse sources such as alpine lakes and swift streams in the high mountain ranges, pothole lakes and sluggish streams in the rolling prairies, and aquifers in bedrock and unconsolidated materials. These water resources are withdrawn for drinking water and used for agriculture and industry and used instream for recreation, wildlife, and hydroelectric power generation (Cannon and Johnson, 2004). Long-term data on water quantity and quality, as well as water use, are important for developing an improved understanding of the water resources of the State.

The U.S. Geological Survey (USGS) has provided water resources data in annual state reports since 1961. In 2006, the
USGS adopted a new national framework for annual waterdata reports (WDR), which will provide access to data from more than 20,000 active sites across the United States. This framework replaces as many as 40,000 printed pages in more than 80 volumes with a simple search tool and interactive map. The site-data sheets (SDSs) provided through this national framework contain all available data for water year 2006 for a particular station including surface water, ground water, water quality, climatological, and biological data. This single waterdata report for the entire Nation is only available online; the annual printed edition of the State reports is discontinued. The data for Montana, along with data from various parts of the Nation, are included in, "Water-Resources Data for the United States, Water Year 2006," which is published as U.S. Geological Survey Water-Data Report WDR-US-2006 and is available online at $h t t p: / / p u b s . w a t e r . u s g s . g o v / w d r 2006$.

\section{Purpose and Scope}

The purpose of this report is to present a compilation of Montana site-data sheets for water year 2006. These data sheets consist of records of discharge and stage of streams; water quality of streams and ground water; stage and contents of lakes and reservoirs; water levels in wells; and precipitation data. Site-data sheets for selected stations in Canada and Wyoming also are included in this report. Additional data collected during water year 2006 at crest-stage gage and miscellaneous-measurement sites were not published. These data are stored in the files of the USGS Montana Water Science Center in Helena and are available on request.

\section{General Hydrologic Setting}

Montana, with an area of about $147,200 \mathrm{mi}^{2}$, is the fourth largest State in the Nation (fig. 1). The major drainage basins in the State are the Hudson Bay basin $\left(465 \mathrm{mi}^{2}\right)$ and the Missouri River basin $\left(120,700 \mathrm{mi}^{2}\right)$ east of the Continental Divide, and the Columbia River basin $\left(26,000 \mathrm{mi}^{2}\right)$ west of the divide. The Hudson Bay and Missouri River basins drain about 82 percent of the State and provide about 40 percent of the total annual streamflow (1971-2000 average). The Columbia River basin drains about 18 percent of the State and provides 
about 60 percent of the total annual streamflow (1971-2000 average) (U.S. Geological Survey, 2006).

The western and southwestern parts of the State are in the Northern and Middle Rocky Mountains (Fenneman and Johnson, 1946). The central and eastern parts of the State are in the Great Plains. The Northern and Middle Rocky Mountains are characterized by rugged mountains and intermontane valleys, whereas the Great Plains consists of rolling to dissected plains and small mountain ranges. Altitude in Montana ranges from more than 12,000 ft (above NGVD 29) in the mountains northeast of Yellowstone National Park to about 1,850 ft (above NGVD 29) where the Kootenai River flows from the northwestern part of the State.

Climate and hydrologic conditions differ substantially across the State. Annual precipitation varies considerably throughout the basins, from about 100-120 in. along the Continental Divide in Glacier National Park to about 8-10 in. in parts of south-central Montana and in some of the western intermontane valleys. The diverse precipitation patterns in Montana result from the effects of geographic and topographic features on warm, moist air from either the Gulf of Mexico or the Pacific Ocean. In mountainous areas, much of the annual precipitation falls as snow during the winter. Although much of the annual precipitation on the Great Plains also falls as snow during the winter, intense rainstorms during the summer can add substantial quantities of precipitation to the annual totals in a short time. In areas east of the mountains, generally one-half of the annual precipitation falls from May through July (U.S. Geological Survey, 2006).

Peak runoff can result from snowmelt, snowmelt mixed with rain, or intense rainfall. In addition, backwater from ice jams commonly creates flooding in many rivers throughout the State. The record flood of April 1952 in northeastern Montana is an example of spring snowmelt flooding. The flood of May 1981 in west-central Montana is an example of flooding caused by snowmelt mixed with rain. The floods of June 1964, June 1975, and May 1978 are examples of flooding predominantly caused by intense rainfall. Flash floods, although restricted in areal extent, are common at times in the north-central and eastern parts of the State. In many areas, peak runoff is stored in reservoirs to decrease flooding. The stored water is used for irrigation (the predominant consumptive use of water statewide), power generation, and recreation (U.S. Geological Survey, 2006).

Surface water throughout the State generally is suitable for most uses except in parts of eastern Montana where, because of large concentrations of dissolved solids and some individual constituents, water-quality standards or recommended guidelines for protecting human health, agricultural irrigation, and freshwater-aquatic life may be exceeded. The ionic composition of surface water is largely influenced by geology and can vary markedly between the western mountains and the eastern plains. In addition, dissolved-solids concentrations can vary substantially between runoff conditions and base flow. In the western mountains, where the rocks generally are older and resistant to weathering, the streamflow typically is a calcium bicarbonate type. The dissolved-solids concentrations in mountain streams commonly are less than $100 \mathrm{mg} / \mathrm{L}$ and seldom exceed $500 \mathrm{mg} / \mathrm{L}$, even during base flow. In the eastern plains, where sedimentary rocks are less resistant to weathering, streamflow commonly is a sodium sulfate type, with dissolved-solids concentrations ranging from about $100 \mathrm{mg} / \mathrm{L}$ during runoff to several thousand $\mathrm{mg} / \mathrm{L}$ during base flow. In the northeastern part of the State, streamflow typically is a sodium bicarbonate type. Snowmelt and intense rainstorms sometimes produce large quantities of runoff that can dilute concentrations of dissolved solids, modify chemical compositions, and increase concentrations of suspended sediment (U.S. Geological Survey, 2006).

The availability and quality of ground water in Montana are largely controlled by the diverse hydraulic and geochemical properties of the various rocks and sediments in which it occurs. In western Montana, ground water of good quality for most uses is available from alluvium along streams and rivers, from basin fill in intermontane valleys, from glacial deposits, and from fractured consolidated rocks. In eastern Montana, ground water is available from alluvial deposits along larger rivers and streams and from sedimentary rocks. Outside of the alluvial valleys, ground-water availability in sedimentary rock is variable. Quality of ground water in eastern Montana ranges from good quality for most uses to water with large amounts of dissolved solids that is not suitable for irrigation, public-water supply, and domestic uses. Throughout Montana, alluvial deposits along streams generally are the most productive aquifers, and wells completed in alluvium along the major streams may produce several hundred gallons per minute. Alluvium can be readily recharged by precipitation, by streams during periods of high flow, and by applied irrigation water. The particle-size distribution and sorting of glacial deposits largely determines their potential for water development. Where coarse, well-sorted outwash gravels are present, the potential for developing large-yield wells is good, whereas yields from wells completed in poorly sorted glacial till generally are limited to a few gallons per minute. Many fractured, consolidated-rock formations are tapped for ground water but, because of the complexity of the geology, fractured rocks might not provide an adequate water supply in all areas. Wells completed in consolidated rocks generally yield only a few gallons per minute. However, several hundred gallons per minute can be obtained from highly fractured or cavernous formations in some areas. The well depth required to reach a given aquifer varies with location (U.S. Geological Survey, 2006). 


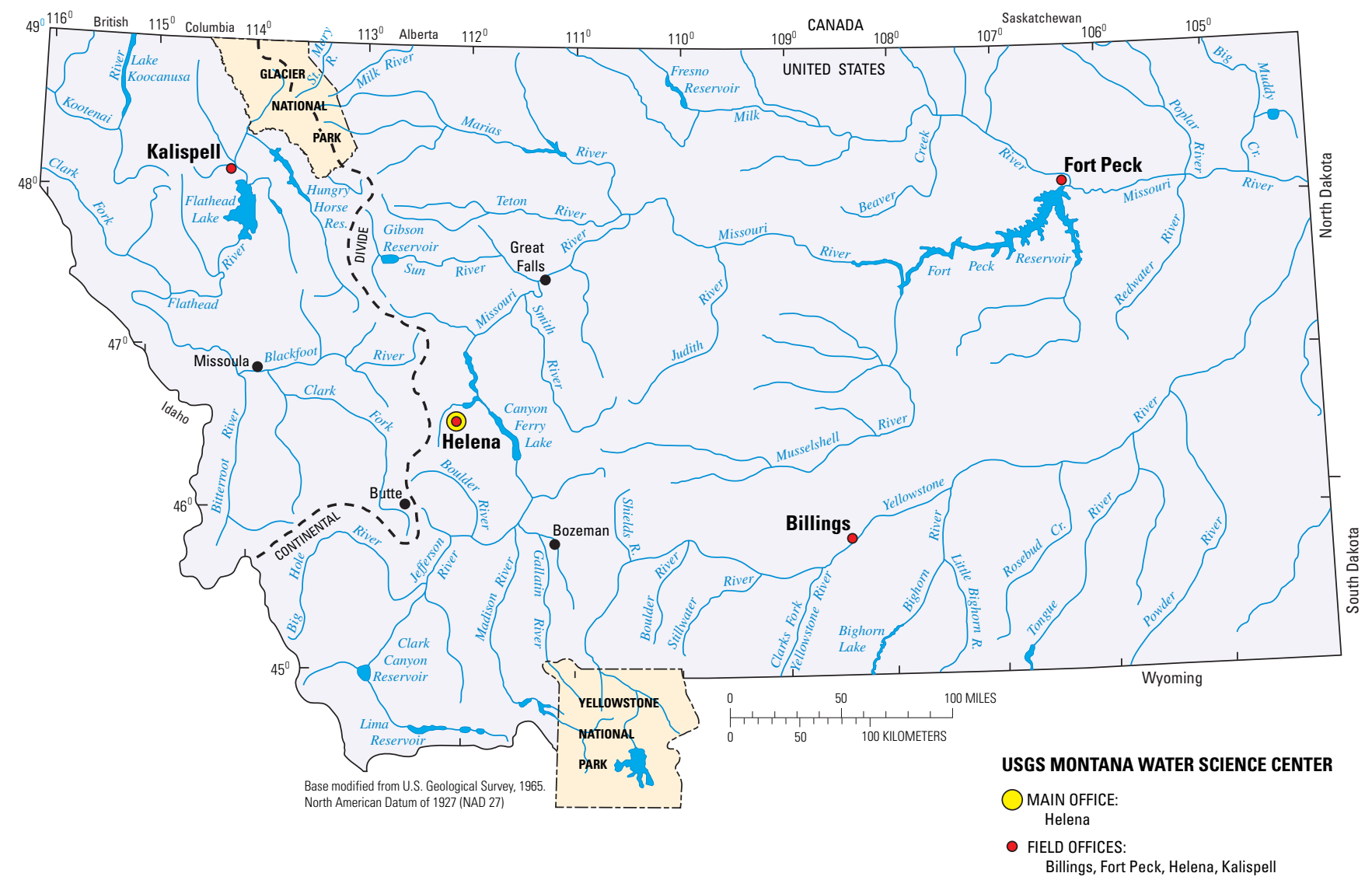

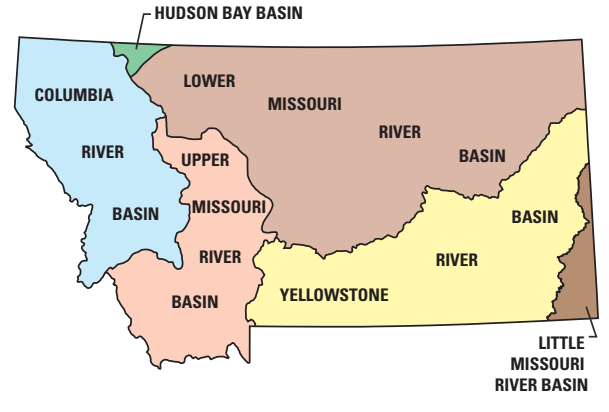

MAJOR DRAINAGE BASINS

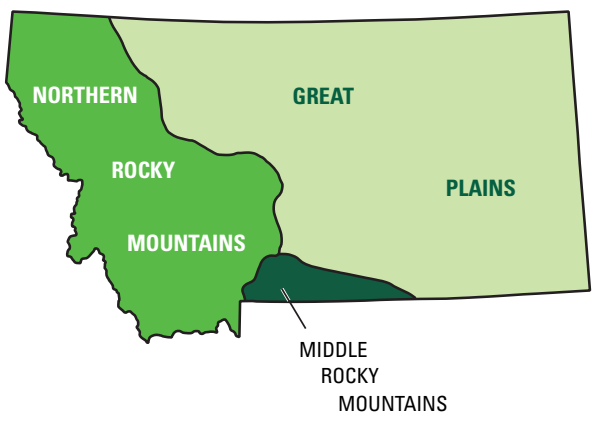

PHYSIOGRAPHIC PROVINCES

Figure 1. General geographic features of Montana. 


\section{Water-Resources Data for Montana}

The USGS operates surface-water, ground-water, waterquality, climatological, and biological stations throughout Montana. The stations change from year to year as objectives are achieved or modified, or funding levels change. Some stations are operated for only a few years and commonly are part of a short-term investigation. Other stations have been in operation for many years and provide a basis for description of long-term hydrologic conditions or trends that represent a wide range of hydrologic or land-use variability. Long-term stations typically are in locations that represent an important water resource in the area and require data on an ongoing basis for various management concerns.

\section{Organization of Water-Resources Data}

The site-data sheets (SDSs) included in this report for surface-water and ground-water have been organized into Appendixes 1-4 according to the major river drainage basins in Montana: Hudson Bay (SDSs indicate Saskatchewan basin), Upper Missouri River, Lower Missouri River, Yellowstone River, and the Pend Oreille subbasin of the Columbia River (SDSs indicate Pend Oreille basin). The stations are listed in downstream order based on their geographic location. Appendix 5 lists stations in Montana's ground-water monitoring network, which are organized by county. Appendix 6 lists stations with precipitation data, which are a part of the National Atmospheric Deposition Program.

Appendixes 1-6 provide the station number, station name, and page number in the portable document format (PDF) file where each SDS can be found in that PDF. The letter after the station name designates the type of data collected at the site: c, chemical; d, discharge; e, elevation or contents; s, sediment; t, daily water temperature; and $\mathrm{u}$, daily specific conductance. In addition, each station listed in appendixes 1-6 has a link for individual viewing. For each SDS, the station name (at the top of the first page for each station) provides a link to the USGS National Water Information System Web (NWISWeb page for that station). This Web site (http://waterdata.usgs.gov/nwis) serves real-time and historical data as well as many other types of water data.

Appendix 7 provides an alphabetical list of all stations for individual viewing. Appendix 8 provides a link to a table of the active (water year 2006) and discontinued stations (having 8-digit stations numbers). The table lists the station number, station name, and drainage area. The period of record for discharge or contents data is given for daily or monthly discharge and annual peaks. The period of record is also given for daily (specific conductance, water temperature, and sediment) and periodic (chemistry, sediment, and biology) water-quality data.

\section{Documentation, Definition of Terms, and Related Water-Resources Information}

Appendix 9 provides documentation about downstream order and station number; numbering system for wells and miscellaneous sites; explanation of stage- and water-discharge records; explanation of precipitation records; explanation of water-quality records and parameter codes; surface-waterquality records; explanation of ground-water-level records and ground-water-quality data. Furthermore, policies and procedures for activities related to the collection of surface-water and water-quality data by the USGS Montana Water Science Center are documented in Lambing (2006), Dodge and Lambing (2006), and White and others (1998).

Appendix 10 presents a list of specialized technical terms related to streamflow, water-quality and other hydrologic data, as used in this report. Not all terms defined in this list apply to data collected in Montana. Other glossaries that also define water-related terms are accessible at $h t t p: / / w a t e r . u s g s$. gov/glossaries.html.

The locations of the stations where data were collected can be viewed using the Water-Data Report Mapper, which is a map interface tool that can be used to view the SDSs. The Mapper (http://web10capp.er.usgs.gov/imf/sites/adr06/ launch2.jsp) allows users to locate stations in the United Sates, the District of Columbia, Puerto Rico, the Virgin Islands, Guam, America Somoa, and affiliated Pacific Islands. The map also allows users to download data for any station. The map is clickable for Montana (or any other area) for detailed viewing.

The USGS provides near real-time stage and discharge data for many of the gaging stations equipped with the necessary telemetry and historical daily mean and peak-flow discharge data for most active or discontinued gaging stations through the World Wide Web. These data may be accessed at http://mt.water.usgs.gov. Water-quality and ground-water data also are available through the Web at http://waterdata.usgs. $\mathrm{gov} / \mathrm{mt} / \mathrm{nwis} / \mathrm{qw}$. In addition, data can be retrieved in various machine-readable formats on various media. Information about the availability of specific types of data or products, and user charges, can be obtained locally from the Montana Water Science Center, Helena, Mont. 


\section{References Cited}

Cannon, M.R., and Johnson, Dave R., 2004, Estimated water use in Montana: U.S. Geological Survey Scientific Investigations Report 2004-5223, 50 p.

Dodge, K.A., and Lambing, J.H., 2006, Quality-assurance plan for the analysis of suspended sediment by the U.S. Geological Survey in Montana: U.S. Geological Survey Open-File Report 2006-1242, 25 p., available at http://pubs.water. usgs.gov/ofr $2006-1242$

Fenneman, N.M. and Johnson, D.W., 1946, Physical divisions of the United States: U.S. Geological Survey, scale $1: 7,000,000,1$ sheet.

Lambing, J.H., comp., 2006, Quality-assurance plan for the water-quality activities of the U.S. Geological Survey Montana Water Science Center: U.S. Geological Survey OpenFile Report 2006-1275, 39 p., available at http://pubs.usgs. gov/of/2006/1275

U.S. Geological Survey, 2006, Water resources data for the United States, water year 2005: U.S. Geological Survey Water-Data Report MT-05-01, 497 p., available at http://pubs.usgs.gov/wdr/2005/wdr-mt-05/

U.S. Geological Survey, 2007, Water resources data for the United States, water year 2006: U.S. Geological Survey Water-Data Report WDR-US-2006, available at http://pubs.water.usgs.gov/wdr2006

White, M.K., Shields, R.R., Dodge, K.A., 1998, Surface-water quality-assurance plan for the Montana District of the U.S. Geological Survey: U.S. Geological Survey Open-File Report 98-173, 54 p. 


\section{Appendix 1. (link) Hudson Bay Basin: Stations-05013900 Grinnell Creek at Grinnell Glacier near Many Glacier, to 05020500 St. Mary River at international boundary and \\ Upper Missouri River Basins: 06006000 Red Rock Creek above Lakes, near Lakeview, to 06090300 Missouri River near Great Falls}

[Type of data collected: c, chemical; d, discharge; e, elevation or contents; s, sediment; t, daily water temperature; and u, daily specific conductance. Each site has an individual PDF.]

Hudson Bay:

05013900 Grinnell Creek at Grinnell Glacier, near Many Glacier (d) (link)

05014300 Swiftcurrent Creek above Swiftcurrent Lake, at Many Glacier (d) (link)

05014500 Swiftcurrent Creek at Many Glacier (d) (link)

05015500 Lake Sherburne at Sherburne (e) (link)

05017500 St. Mary River near Babb (d) (link)

05018000 St. Mary Canal at intake, near Babb (d) (link)

05018500 St. Mary Canal at St. Mary Crossing, near Babb (d) (link)

05020500 St. Mary River at international boundary (d) (link)

Upper Missouri River Basin:

06006000 Red Rock Creek above Lakes, near Lakeview (d) (link)

06012000 Lima Reservoir near Monida (e) (link)

06012500 Red Rock River below Lima Reservoir, near Monida (d) (link)

06015300 Clark Canyon Reservoir near Grant (e) (link)

06016000 Beaverhead River at Barretts (d) (link)

06017000 Beaverhead River at Dillon (d) (link)

06018500 Beaverhead River near Twin Bridges (d) (link)

06019500 Ruby River above reservoir, near Alder (d) (link)

06020600 Ruby River below reservoir, near Alder (d) (link)

06024450 Big Hole River below Big Lake Creek, at Wisdom (d, t) (link)

06024540 Big Hole River below Mudd Creek, near Wisdom (d) (link)

06025500 Big Hole River near Melrose (d, t) (link)

06026210 Big Hole River near Glen (d) (link)

06026500 Jefferson River near Twin Bridges (d) (link)

06027600 Jefferson River at Parsons Bridge, near Silver Star (d, t) (link)

462517112173001 Local number 08N06W25AABB01, Luttrell Well EPA-1 (e, c ) (link)

462507112170601 Local number 108N05W30BBCD01, Luttrell Well EPA-6 (e, c) (link)

462503112172302 Local number 08N06W25ADAC02, Luttrell Well EPA-4S (e, c) (link)

462503112172301 Local number 08N06W25ADAC01, Luttrell Well EPA-4 (e, c) (link)

462500112170701 Local number 08N05W30BCBD01, Luttrell Well EPA-5 (e, c) (link)

462347112173301 Local number 08N06W36DCAA01, Buckeye Well BTMW-9 (e, c) (link)

462344112173701 Local number 08N06W36DCAC01, Buckeye Well BTMW-1 (e, c) (link)

462342112174201 Local number 08N06W36DCBD02, Buckeye Well BTMW-3 (e, c) (link)

462342112174601 Local number 08N06W36DCBC01, Buckeye Well BTMW-6 (e, c) (link)

462341112174601 Local number 08N06W36DCCB01, Buckeye Well BTMW-7 (e, c) (link)

462342112174801 Local number 08N06W36DCBC02, Buckeye Well BTMW-8 (e, c) (link)

462347112180401 Basin Creek below Buckeye Mine near logging road, near Basin (c, s) (link)

462500112170201 Unnamed stream (LAD 1) draining Luttrell repository area, near Rimini (c) (link)

462500112170501 Unnamed stream (LAD 2) draining Luttrell repository area, near Rimini (c) (link)

462442112174602 Unnamed tributary to Grub Creek at mouth, SS No. 6, near Rimini (c) (link)

462442112174601 Grub Creek above mouth of unnamed tributary (GC03), near Rimini (c) (link)

462155112181501 Jack Creek above Bullion Mine tributary, near Basin (c, s) (link)

462120112173701 Bullion Mine Adit near Basin (c) (link)

462153112181701 Bullion Mine tributary at mouth, near Basin (c, s) (link)

462047112201901 Jack Creek at mouth, near Basin (c, s) (link)

06031600 Basin Creek at Basin (c, s) (link) 
461905112144201 Cataract Creek above Uncle Sam Gulch, near Basin (c, s) (link)

462053112153601 Crystal Mine Adit near Basin (c) (link)

461904112144401 Uncle Sam Gulch at mouth, near Basin (c, s) (link)

06031960 Cataract Creek at Basin (c, s) (link)

06032400 Boulder River below Little Galena Gulch, near Basin (c, s) (link)

06033000 Boulder River near Boulder (d) (link)

06035000 Willow Creek near Harrison (d, t) (link)

06036650 Jefferson River near Three Forks (d) (link)

06036905 Firehole River near West Yellowstone (d, t) (link)

06036940 Tantalus Creek at Norris Junction, Yellowstone National Park (d, t) (link)

06037100 Gibbon River at Madison Junction, Yellowstone National Park (d, t) (link)

06037500 Madison River near West Yellowstone (d) (link)

06038000 Hebgen Lake near West Yellowstone (e) (link)

06038500 Madison River below Hebgen Lake, near Grayling (d) (link)

06038800 Madison River at Kirby Ranch, near Cameron (d) (link)

06040500 Ennis Lake near McAllister (e) (link)

06040800 Madison River above powerplant, near McAllister (d) (link)

06041000 Madison River below Ennis Lake, near McAllister (d, t) (link)

06043500 Gallatin River near Gallatin Gateway (d) (link)

06048700 East Gallatin River below Bridger Creek, near Bozeman (d) (link)

06052500 Gallatin River at Logan (d, t) (link)

460720111255101 Upper Toston Reservoir near Toston (c) (link)

460719111243201 Lower Toston Reservoir near Toston (c) (link)

06054500 Missouri River at Toston (d, t) (link)

462334111311701 Upper Canyon Ferry Lake near Townsend (c) (link)

462726111320201 Canyon Ferry Lake near Duck Creek, near Townsend (c) (link)

463104111343001 Central Canyon Ferry Lake near Townsend (c) (link)

463514111393501 Canyon Ferry Lake near Avalanche Creek, near Townsend (c) (link)

463811111420001 Lower Canyon Ferry Lake near Townsend (c) (link)

06058500 Canyon Ferry Lake near Helena (e) (link)

462522112172401 Local number 08N06W24DDCD01, Luttrell Well EPA-3 (c) (link)

462522112172402 Local number 08N06W24DDCD02, Luttrell Well EPA-3S (c) (link)

462720112165101 Tenmile Creek above Monitor Creek, near Rimini (c) (link)

462542112173101 Monitor Creek SS 12 near Rimini (c) (link)

462721112164801 Monitor Creek at mouth (MCM), near Rimini (c) (link)

462544112162001 Ruby Creek RC2A above Scott Reservoir, near Rimini (c) (link)

462657112143501 Banner Creek at bridge, 0.5 mile above City diversion, near Rimini (c, s) (link)

462838112143901 Poison Creek at mouth near Rimini (c, s) (link)

462853112144101 Tenmile Creek above City diversion, near Rimini (c, s) (link)

462758112123001 Beaver Creek tributary No. 2 near Rimini (c, s) (link)

462922112145401 Tenmile Creek below Spring Creek, at Rimini (c, s) (link)

462932112145801 Moores Spring Creek at mouth, near Rimini (c, s) (link)

462818112171001 Minnehaha Creek above Justice Mine, near Rimini (c, s) (link)

462844112165401 Minnehaha Creek above Armstrong Mine, near Rimini (c, s) (link)

462917112165601 Minnehaha Creek below Armstrong Mine, near Rimini (c, s) (link)

462918112170801 Beattrice Mine tributary at mouth, near Rimini (c, s) (link)

463023112153701 Minnehaha Creek above City diversion, near Rimini (c, s) (link)

06061500 Prickly Pear Creek near Clancy (d) (link)

06062500 Tenmile Creek near Rimini (d, c, s) (link)

06064500 Lake Helena near Helena (e) (link)

06065000 Hauser Lake near Helena (e) (link)

06065500 Missouri River below Hauser Dam, near Helena (d) (link)

06066000 Holter Lake near Wolf Creek (e) (link)

06066500 Missouri River below Holter Dam, near Wolf Creek (d, t) (link)

06071300 Little Prickly Pear Creek at Wolf Creek (d) (link)

06073500 Dearborn River near Craig (d, t) (link) 
06076560 Smith River below Newlan Creek, near White Sulphur Springs (d) (link)

06077200 Smith River below Eagle Creek, near Fort Logan (d, t) (link)

06077500 Smith River near Eden (d) (link)

06078200 Missouri River near Ulm (d) (link)

06079500 Gibson Reservoir near Augusta (e) (link)

06085800 Sun River at Simms (d) (link)

06088300 Muddy Creek near Vaughn (d, s) (link)

06088500 Muddy Creek at Vaughn (d, c, s) (link)

06089000 Sun River near Vaughn (d, c, s, t) (link)

06090300 Missouri River near Great Falls (d) (link) 


\section{Appendix 2. (link) Lower Missouri River Basin: Stations-06090650 Lake Creek near Power, to 06185500 Missouri River near Culbertson}

[Type of data collected: c, chemical; d, discharge; e, elevation or contents; s, sediment; $t$, daily water temperature; and u, daily specific conductance. Each site has an individual PDF.]

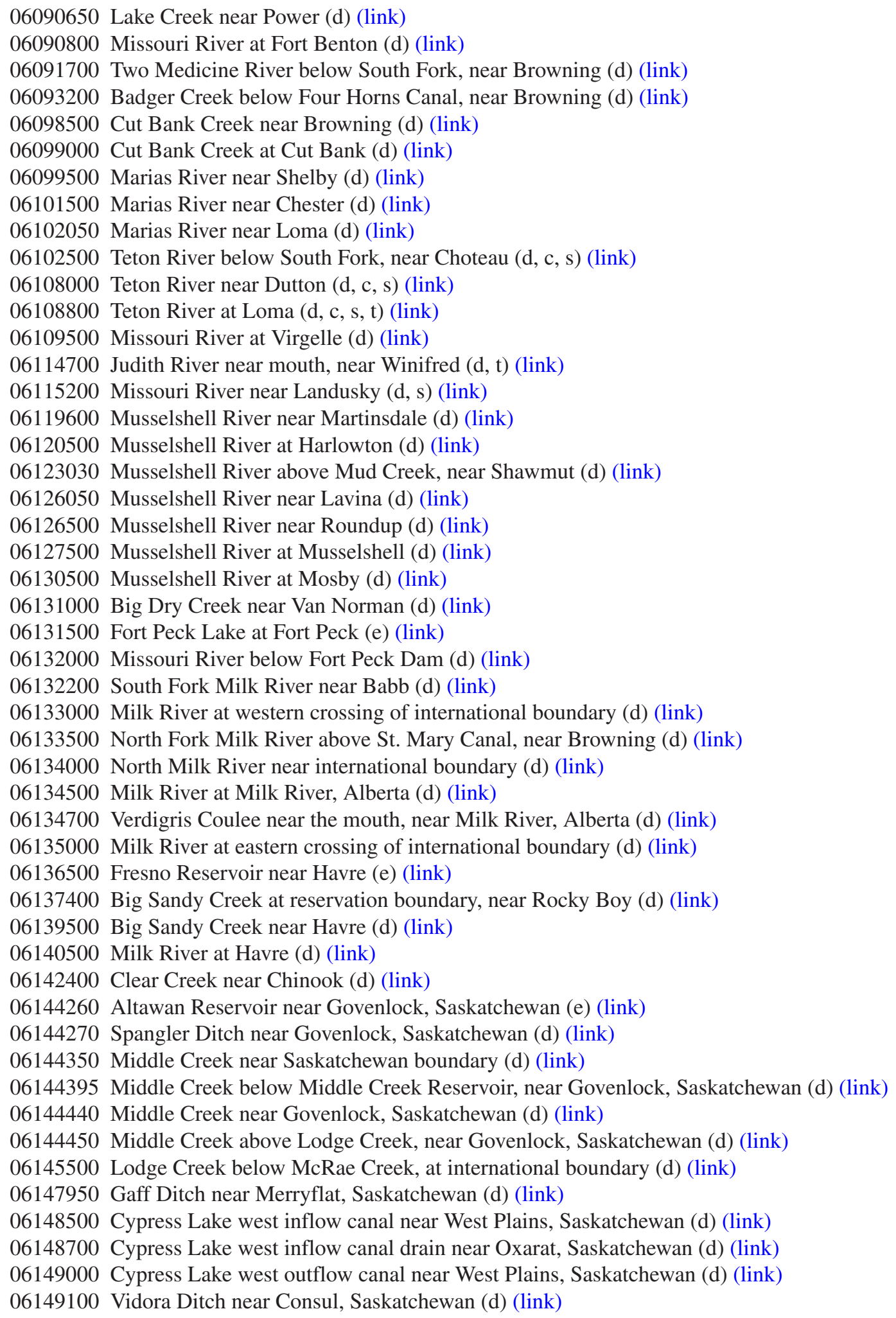


06149200 Richardson Ditch near Consul, Saskatchewan (d) (link)

06149300 McKinnon Ditch near Consul, Saskatchewan (d) (link)

06149400 Nashlyn Canal near Consul, Saskatchewan (d) (link)

06149500 Battle Creek at international boundary (d) (link)

06151500 Battle Creek near Chinook (d) (link)

05154100 Milk River near Harlem (d) (link)

06154400 Peoples Creek near Hays (d) (link)

06154410 Little Peoples Creek near Hays (d) (link)

06154550 Peoples Creek below Kuhr Coulee, near Dodson (d) (link)

06155030 Milk River near Dodson (d) (link)

06155900 Milk River at Cree Crossing, near Saco (d) (link)

06156500 Belanger Creek diversion canal near Vidora, Saskatchewan (d) (link)

06157000 Cypress Lake near Consul, Saskatchewan (e) (link)

06157500 Cypress Lake east outflow canal near Vidora, Saskatchewan (d) (link)

06158500 Eastend Canal at Eastend, Saskatchewan (d) (link)

06159000 Eastend Reservoir near Eastend, Saskatchewan (e) (link)

06161300 Huff Lake pumping canal near Val Marie, Saskatchewan (d) (link)

06161500 Huff Lake gravity canal near Val Marie, Saskatchewan (d) (link)

06162000 Huff Lake near Val Marie, Saskatchewan (e) (link)

06162500 Newton Lake main canal near Val Marie, Saskatchewan (d) (link)

06163000 Newton Lake near Val Marie, Saskatchewan (e) (link)

06164000 Frenchman River at international boundary (d) (link)

06164510 Milk River at Juneberg Bridge, near Saco (d) (link)

06166000 Beaver Creek below Guston Coulee, near Saco (d) (link)

06169500 Rock Creek below Horse Creek, near international boundary (d) (link)

06172310 Milk River at Tampico (d) (link)

06174500 Milk River at Nashua (d) (link)

06177000 Missouri River near Wolf Point (d) (link)

06178000 Poplar River at international boundary (d, c, s) (link)

06178500 East Poplar River at international boundary (d, c, s, u) (link)

06181000 Poplar River near Poplar (d, c, s) (link)

06183450 Big Muddy Creek near Antelope (d) (link)

06183700 Big Muddy Creek diversion canal near Medicine Lake (d) (link)

06183750 Lake Creek near Dagmar (d) (link)

06183800 Cottonwood Creek near Dagmar (d) (link)

06183850 Sand Creek near Dagmar (d) (link)

06185500 Missouri River near Culbertson (d, c, s) (link) 


\section{Appendix 3. (link) Yellowstone River Basin: Stations-06186500 Yellowstone River at Yellowstone Lake outlet, Yellowstone National Park, to 06329500 Yellowstone River near Sidney}

[Type of data collected: c, chemical; d, discharge; e, elevation or contents; s, sediment; $t$, daily water temperature; and u, daily specific conductance. Each site has an individual PDF.]

06186500 Yellowstone River at Yellowstone Lake outlet, Yellowstone National Park (d) (link)

06187915 Soda Butte Creek at Park boundary, at Silver Gate (d, t) (link)

06187950 Soda Butte Creek near Lamar Ranger Station, Yellowstone National Park (d, (link)

06188000 Lamar River near Tower Falls Ranger Station, Yellowstone National Park (d) (link)

06190540 Boiling River at Mammoth, Yellowstone National Park (d, t) (link)

06191000 Gardner River near Mammoth, Yellowstone National Park (d) (link)

06191500 Yellowstone River at Corwin Springs (d) (link)

06192500 Yellowstone River near Livingston (d) (link)

06195600 Shields River near Livingston (d) (link)

06200000 Boulder River at Big Timber (d) (link)

06204000 Mystic Lake near Roscoe (e) (link)

06204050 West Rosebud Creek near Roscoe (d) (link)

06204070 West Rosebud Creek at Emerald Lake Campground, near Roscoe (d) (link)

06205000 Stillwater River near Absarokee (d) (link)

06207500 Clarks Fork Yellowstone River near Belfry (d) (link)

06208500 Clarks Fork Yellowstone River at Edgar (d) (link)

06209500 Rock Creek near Red Lodge (d) (link)

06211000 Red Lodge Creek above Cooney Reservoir, near Boyd (d) (link)

06211500 Willow Creek near Boyd (d) (link)

06214500 Yellowstone River at Billings (d) (link)

06216000 Pryor Creek at Pryor (d) (link)

06286400 Bighorn Lake near St. Xavier (e) (link)

06287000 Bighorn River near St. Xavier (d) (link)

06289000 Little Bighorn River at State line, near Wyola (d) (link)

06290000 Pass Creek near Wyola (d) (link)

06291500 Lodge Grass Creek above Willow Creek diversion, near Wyola (d) (link)

06294000 Little Bighorn River near Hardin (d) (link)

06294500 Bighorn River above Tullock Creek, near Bighorn (d) (link)

06295000 Yellowstone River at Forsyth (d) (link)

06295113 Rosebud Creek at reservation boundary, near Kirby (d, c, s, u) (link)

06295250 Rosebud Creek near Colstrip (d) (link)

06296003 Rosebud Creek at mouth, near Rosebud (d, c, s) (link)

06299980 Tongue River at Monarch, Wyoming (d, c, s, u) (link)

06305700 Goose Creek near Acme, Wyoming (d, c, s, u) (link)

450137106595101 Youngs Creek near reservation boundary, near Decker (c) (link)

445832106551401 Youngs Creek above mouth, near Decker (c) (link)

445817106544601 Youngs Creek at mouth, near Decker (c) (link)

445957106524701 Tongue River below Youngs Creek, near Decker (c) (link)

06306100 Squirrel Creek near Decker (c) (link)

445955106515801 Discharge from coal-bed methane production facilities, permit No. MT-0030457-005 (c) (link)

06306250 Prairie Dog Creek near Acme, Wyoming (d, c, s, u) (link)

445955106524801 Discharge from coal-bed methane production facilities, permit No. MT-0030457-008 (c) (link)

451607106372801 Tongue River at Prairie Dog Creek, near Birney (c) (link)

450007106495201 Discharge from coal-bed methane production facilities, permit No. MT-0030457-013 (c) (link)

06306300 Tongue River at State line, near Decker (d, c, s, u) (link)

06307000 Tongue River Reservoir near Decker (e) (link)

06307500 Tongue River at Tongue River Dam, near Decker (d, c, s, u) (link)

06307570 Hanging Woman Creek below Horse Creek, near Birney (c) (link)

451340106295501 Hanging Woman Creek below Hay Gulch, near Birney (c) (link) 
06307600 Hanging Woman Creek near Birney (d, c, s, u) (link)

06307616 Tongue River at Birney Day School Bridge, near Birney (d, c, s, u) (link)

451732106085001 Otter Creek below Taylor Creek, near Otter (c) (link)

06307740 Otter Creek at Ashland (d, c, s, u) (link)

06307830 Tongue River below Brandenberg Bridge, near Ashland (d, c, s, u) (link)

06307990 Tongue River above T\&Y Diversion Dam, near Miles City (d, c, s, u) (link)

06308170 Little Pumpkin Creek near Volborg (c, s) (link)

454739105430701 Pumpkin Creek below Little Pumpkin Creek, near Volborg (c, s) (link)

454246105440001 Pumpkin Creek above Camp Creek, near Volborg (c, s) (link)

455136105401001 Pumpkin Creek above Deer Creek, near Volborg (c, s) (link)

06308400 Pumpkin Creek near Miles City (d, c, s, u) (link)

06308500 Tongue River at Miles City (d, c, s, u) (link)

06309000 Yellowstone River at Miles City (d) (link)

06324500 Powder River at Moorhead (d, c, s, u) (link)

06324710 Powder River at Broadus (c) (link)

06325500 Little Powder River near Broadus (c, s) (link)

453209105201201 Powder River below Little Powder River, near Broadus (c) (link)

06326500 Powder River near Locate (d, c, s) (link)

06327500 Yellowstone River at Glendive (d) (link)

06329500 Yellowstone River near Sidney (d, c, s) (link) 


\section{Appendix 4. (link) Columbia River Basin (Pend Oreille Basin): Stations-12301300 Tobacco River near Eureka, to 12391400 Clark Fork below Noxon Rapids Dam, near Noxon}

[Type of data collected: c, chemical; d, discharge; e, elevation or contents; s, sediment; $t$, daily water temperature; and u, daily specific conductance. Each site has an individual PDF.]

12301300 Tobacco River near Eureka (d) (link)

12301920 Lake Koocanusa near Libby (e) (link)

12301933 Kootenai River below Libby Dam, near Libby (d) (link)

12302055 Fisher River near Libby (d) (link)

12304500 Yaak River near Troy (d) (link)

12323230 Blacktail Creek at Harrison Avenue, at Butte (c, s) (link)

12323240 Blacktail Creek at Butte (d) (link)

12323250 Silver Bow Creek below Blacktail Creek, at Butte (d, c, s) (link)

12323600 Silver Bow Creek at Opportunity (d, c, s) (link)

12323670 Mill Creek near Anaconda (d, c, s) (link)

12323700 Mill Creek at Opportunity (d, c, s) (link)

12323710 Willow Creek near Anaconda (d, c, s) (link)

12323720 Willow Creek at Opportunity (d, c, s) (link)

12323750 Silver Bow Creek at Warm Springs (d, c, s) (link)

12323760 Warm Springs Creek near Anaconda (d, c, s) (link)

12323770 Warm Springs Creek at Warm Springs (d, c, s, t) (link)

12323800 Clark Fork near Galen (d, c, s) (link)

12323840 Lost Creek near Anaconda (d, c, s) (link)

12323850 Lost Creek near Galen (d, c, s) (link)

12324200 Clark Fork at Deer Lodge (d, c, s) (link)

12324590 Little Blackfoot River near Garrison (d) (link)

12324680 Clark Fork at Goldcreek (d, c, s) (link)

12325500 Flint Creek near Southern Cross (d) (link)

12329500 Flint Creek at Maxville (d) (link)

12330000 Boulder Creek at Maxville (d) (link)

12331800 Clark Fork near Drummond (dcs) (link)

12332000 Middle Fork Rock Creek near Philipsburg (d) (link)

12334510 Rock Creek near Clinton (d, t) (link)

12334550 Clark Fork at Turah Bridge, near Bonner (d, c, s) (link)

12335100 Blackfoot River above Nevada Creek, near Helmville (d) (link)

12335500 Nevada Creek above reservoir, near Helmville (d) (link)

12337800 Nevada Creek at mouth, near Helmville (d, t) (link)

12338300 North Fork Blackfoot River above Dry Gulch, near Ovando (d) (link)

12340000 Blackfoot River near Bonner (d, c, s, t) (link)

465224113525501 Blackfoot River at Milltown (c) (link)

12340500 Clark Fork above Missoula (d, c, s) (link)

12342500 West Fork Bitterroot River near Conner (d) (link)

12343400 East Fork Bitterroot River near Conner (c, s) (link)

12344000 Bitterroot River near Darby (d, c, s, t) (link)

12350250 Bitterroot River at Bell Crossing, near Victor (d) (link)

12351200 Bitterroot River near Florence (d, c, s) (link)

12352500 Bitterroot River near Missoula (d, c, s, t) (link)

12353000 Clark Fork below Missoula (d) (link)

12354000 St. Regis River near St. Regis (d) (link)

12354500 Clark Fork at St. Regis (d, c, s) (link)

12355000 Flathead River at Flathead, British Columbia (d, c, s) (link)

12355500 North Fork Flathead River near Columbia Falls (d, t) (link)

12358500 Middle Fork Flathead River near West Glacier (d) (link)

12359800 South Fork Flathead River above Twin Creek, near Hungry Horse (d) (link) 
12362000 Hungry Horse Reservoir near Hungry Horse (e) (link)

12362500 South Fork Flathead River near Columbia Falls (d, t) (link)

12363000 Flathead River at Columbia Falls (d, c, s, t) (link)

12365000 Stillwater River near Whitefish (d) (link)

12366000 Whitefish River near Kalispell (d) (link)

12370000 Swan River near Bigfork (d) (link)

12371000 Turtle Lake near Polson (e) (link)

12371550 Flathead Lake at Polson (e) (link)

12372000 Flathead River near Polson (d) (link)

12372500 Little Bitterroot Lake near Marion (e) (link)

12373500 Hubbart Reservoir near Niarada (e) (link)

12374250 Mill Creek above Bassoo Creek, near Niarada (d) (link)

12375000 Upper Dry Fork Reservoir near Lonepine (e) (link)

12375500 Dry Fork Reservoir near Lonepine (e) (link)

12375900 South Crow Creek near Ronan (d) (link)

12376700 Lower Crow Reservoir near Charlo (e) (link)

12377150 Mission Creek above reservoir, near St. Ignatius (d) (link)

12377200 Mission Reservoir near St. Ignatius (e) (link)

12377300 St. Mary's Lake near St. Ignatius (e) (link)

12377900 Pablo Reservoir near Polson (e) (link)

12378200 McDonald Reservoir near Charlo (e) (link)

12378300 Kicking Horse Reservoir near Charlo (e) (link)

12378400 Ninepipe Reservoir near Charlo (e) (link)

12380000 Upper Jocko Lake near Arlee (e) (link)

12380500 Lower Jocko Lake near Arlee (e) (link)

12381400 South Fork Jocko River near Arlee (d) (link)

12383500 Big Knife Creek near Arlee (d) (link)

12387450 Valley Creek near Arlee (d) (link)

12388200 Jocko River at Dixon (d) (link)

12388400 Revais Creek below West Fork, near Dixon (d) (link)

12388700 Flathead River at Perma (d, c, s, t) (link)

12389000 Clark Fork near Plains (d) (link)

12389500 Thompson River near Thompson Falls (d) (link)

12390000 Thompson Falls Reservoir at Thompson Falls (e) (link)

12390700 Prospect Creek at Thompson Falls (d) (link)

12391300 Noxon Rapids Reservoir near Noxon (e) (link)

12391400 Clark Fork below Noxon Rapids Dam, near Noxon (d) (link) 


\section{Appendix 5. (link) Montana's Ground-Water Monitoring Network}

[Type of data collected: c, chemical; d, discharge; e, elevation or contents; s, sediment; $t$, daily water temperature; and $u$, daily specific conductance. Each site has an individual PDF.]

Beaverhead County, 450937112393701 Well 08S09W01CCCC01 (e) (link) Beaverhead County, 450524112380701 Well 08S08W31CCAA01 (e) (link) Cascade County, 473031111185001 Well 20N03E11ABAD01 (e) (link) Cascade County, 472203111112602 Well 19N04E26CACC02 (e) (link) Gallatin County, 454809111095401 Well 01N04E25DCDD01 (e) (link) Garfield County, 470709106061401 Well 16N44E25BBAC01 (e) (link) Lake County, 470946114013201 Well 16N19W08ACBD01 (e) (link) McCone County, 480034105195401 Well 26N49E13ACAB01 (e) (link) Mineral County, 471804115060501 Well 18N28W24DCBA01 (e) (link) Mineral County, 471814115052901 Well 18N27W19CBBD01 (e) (link) Mineral County, 471751115045001 Well 18N27W30ABBA01 (e) (link) Mineral County, 471207114555401 Well 17N26W30DAAD01 (e) (link) Powder River County, 453107106110601 Well 04S45E04BDDB01 (e) (link) Powell County, 470049113035401 Well 15N12W36BCDD01 (e) (link) Ravalli County, 463750114033001 Well 10N20W13BBA 01 (e) (link) Ravalli County, 461518114090802 Well 06N20W19CCCC02 (e) (link) Rosebud County, 451746106301101 Well 06S43E19DDBA02 (e) (link) Sanders County, 474251114385201 Well 23N24W34ADAA01 (e) (link) Sanders County, 475316115381901 Well 25N31W30DCCC01 (e) (link) Sanders County, 472837114540201 Well 20N26W22CBBA01 (e) (link) Sanders County, 472448114495201 Well 19N25W07CDDA01 (e) (link) Sanders County, 472257114473701 Well 19N25W28BABB01 (e) (link) Sheridan County, 483650104084001 Well 33N58E17ADDD01 (e) (link) Sheridan County, 483318104105402 Well 32N58E04DBBD02 (e) (link) Teton County, 474005111583803 Well 22N03W15BAAD03 (e) (link) 


\section{Appendix 6. (link) National Atmospheric Deposition Program Precipitation Stations}

[Each site has an individual PDF.]

462905112035401 McBeath Residence near Clancy, MT07 (link)

482958109475101 Northern Montana Agricultural Research Center near Havre, MT98 (link) 
Appendix 7. (link Alphabetical Listing of Site-Data Sheets for Montana

Appendix 8. (link) Active and Discontinued Stations

Appendix 9. (link) Documentation

Appendix 10. (link) Definition of Terms 